\title{
Data report: solid-phase major and minor elements and iron and sulfur species in sediments of the Anholt Basin, Baltic Sea, collected during IODP Expedition $347^{1}$
}

\author{
Jessica B. Volz, ${ }^{2}$ Natascha Riedinger, ${ }^{3}$ Dalton S. Hardisty, ${ }^{4}$ and Sabine Kasten ${ }^{2, ~ 5, ~} 6$ \\ Keywords: Integrated Ocean Drilling Program, IODP, Expedition 347, Greatship Manisha, \\ Baltic Sea Paleoenvironment, Anholt Basin, Kattegat, Site M0060, bulk sediment \\ composition, iron oxides, iron sulfides
}

\section{Abstract}

In this report, we present bulk solid-phase major and minor element contents and Fe and S species in sediments from Site M0060 in the Anholt Basin recovered during Integrated Ocean Drilling Program Expedition 347 to the Baltic Sea. Site M0060 is characterized by alternating sand- and clay-/silt-dominated sediment sequences that indicate deposition under brackish-marine and limnic conditions, respectively. We use Al-normalized elemental ratios and transition metal data to characterize the different sediment sequences and to study the impact of early diagenetic processes on the abundance and reactivity of Fe oxide and Fe sulfide mineral phases across lithologic boundaries.

Ratios of $\mathrm{Fe} / \mathrm{Al}$ and $\mathrm{Mn} / \mathrm{Al}$ exceed the continental crustal average in the clay-/silt-dominated sequences, whereas low ratios are associated with the sandy units. About $10 \%-20 \%$ of the total bulk Fe content is associated with Fe oxides and Fe sulfides, whereas the major Fe fraction is bound in clay minerals. The transition metals ( $\mathrm{V}, \mathrm{Ni}, \mathrm{Cr}$, and $\mathrm{Co}$ ) correlate with the depth profile of $\mathrm{Fe} / \mathrm{Al}$, which indicates that they are adsorbed onto Fe oxides and concomitantly deposited. Sequential leaching reveals that magnetite is the most abundant Fe oxide phase. Leached contents approach $1 \mathrm{wt} \%$ followed by crystalline and easily reducible Fe oxides. Pyrite is the dominant Fe sulfide phase and is enriched at several lithologic boundaries that can likely be associated with the formation of pyrite. Pyrite is formed through the reaction of Fe monosulfides with (1) polysulfides and/or $\mathrm{S}^{0}$ in zones dominated by organoclastic sulfate and Fe oxide reduction and (2) sulfide released during the anaerobic oxidation of methane.

\section{Introduction}

Integrated Ocean Drilling Program Expedition 347, Baltic Sea Paleoenvironment, was designed to characterize the geological development of the Baltic Sea (Andrén et al., 2015a), which has been highly affected by extreme climatic variations regarding ice cover, temperature, salinity, and biological communities and recently by human activities (e.g., Eronen, 1990; Björck, 1995; Richardson and Heilmann, 1995; Kotthoff et al., 2017). For this purpose, sediment cores have been retrieved from different settings in the Baltic Sea covering the last glacial-interglacial cycle (Andrén et al., 2015a). Site M0060, the focus of this study, was drilled close to Anholt Island, located in the Kattegat region of the Baltic Sea (Andrén et al., 2015b).

The Kattegat is a shallow sea area connecting the Baltic Proper and the North Sea via the Skagerrak (e.g., Björck, 1995). Low-saline (14-17 PSU) surface waters flow northward, and oxygenated, relatively saline ( $>24$ PSU) bottom waters enter from the North Sea (e.g., Svansson, 1975; Stigebrandt, 1983; Kotthoff et al., 2017). The Kattegat area was highly affected by Weichselian ice advances of the Scandinavian ice sheet into Denmark (e.g., Andrén et al., 2011). Because of repeated glaciation and melting phases of the Scandinavian ice sheet, water level and salinity constantly shifted during the Quaternary (e.g., Miettinen, 2004), and deposits (till, sand, and clay) may have been displaced by the glacier (Andrén et al., 2015a).

Site M0060 is situated in an erosional valley formed during subglacial meltwater erosion related to repeated glacial phases during the Quaternary. Because of relatively high sedimentation rates since the last glacial cycle, the Anholt Basin contains a high-resolution

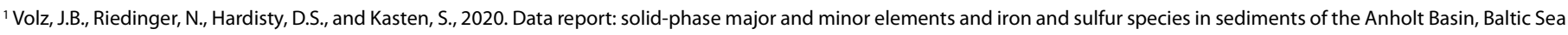
collected during IODP Expedition 347. In Andrén, T., Jørgensen, B.B., Cotterill, C., Green, S., and the Expedition 347 Scientists, Proceedings of the Integrated Ocean Drilling Program, 347: College Station, TX (Integrated Ocean Drilling Program). https://doi.org/10.2204/iodp.proc.347.202.2020

2 Alfred Wegener Institute Helmholtz Centre for Polar and Marine Research, Germany. Correspondence author: jessica.volz@awi.de

${ }^{3}$ Boone Pickens School of Geology, Oklahoma State University, USA.

${ }^{4}$ Department of Earth and Environmental Sciences, Michigan State University, USA.

${ }^{5}$ Faculty of Geosciences, University of Bremen, Germany.

${ }^{6}$ MARUM - Center for Marine Environmental Sciences, University of Bremen, Germany.

MS 347-202: Received 27 April 2020 · Accepted 10 August $2020 \cdot$ Published 14 October 2020

This work is distributed under the Creative Commons Attribution 4.0 International (CC BY 4.0) license. (c) BY
} 
sediment sequence (Andrén et al., 2015a). Site M0060 is characterized by mass transported, unsorted to poorly sorted diamict Lithostratigraphic Unit VII in the lowermost part of the core (Andrén et al., 2015b). On top of this unit, alternating sandy and silty sequences dominate (Units VI-I), and varved glacial clays (Units III-II) indicate deposition in a glacial lake or marginal marine environment. Based on pore water chloride data, sand-dominated Units IV and VI indicate freshwater influence (Andrén et al., 2015b).

Solid-phase major and minor element contents can be used to characterize sediment sequences that accumulated in the Anholt Basin during various depositional environments throughout the last interglacial-glacial cycle (Andrén et al., 2015b). These deposits may be geochemically altered because of early diagenetic processes driven by microbial organic matter degradation, namely organoclastic sulfate and Fe oxide reduction (e.g., Froelich et al., 1979; Jørgensen, 1982; Thamdrup et al., 1994), and through the anaerobic oxidation of methane (AOM) (Niewöhner et al., 1998; Hensen et al., 2003; Riedinger et al., 2005; Jørgensen and Kasten, 2006; Egger et al., 2017). Thus, the biogeochemical cycles of Fe, C, and S in marine sediments are closely linked (e.g., Berner, 1970).

The abundance of Fe sulfides in anoxic sediments is mostly dependent on the availability of (1) pore water sulfide released during organoclastic sulfate reduction and through AOM with sulfate and, concomitantly, (2) pore water Fe released during organoclastic Fe oxide reduction and through Fe-mediated AOM as well as the content of reactive solid-phase $\mathrm{Fe}$ as scavengers for the produced pore water sulfide (e.g., Goldhaber and Kaplan, 1974; Jørgensen, 1977, 1982; Berner, 1984; Riedinger et al., 2014; Egger et al., 2015b, 2017; Oni et al., 2015; Aromokeye et al., 2020). Via the accumulation of intermediate metastable Fe monosulfides (mackinawite and greigite) (Rickard, 1995), pyrite can be formed through the reaction of Fe monosulfides with sulfides (Rickard, 1997; Thiel et al., 2019), polysulfides, and $S^{0}$ (Berner, 1970; Rickard, 1975; Luther, 1991).

The linkage between the Fe and S cycling in connection with other redox-sensitive elements (e.g., Mo and Mn) has been used for the reconstruction of past water column and sediment redox conditions (e.g., Raiswell and Canfield, 1998; Brumsack, 2006). At several sites in the Baltic Sea, deep sediment records have revealed past anoxic water column conditions during temporarily different depositional settings (e.g., Hardisty et al., 2016; Dijkstra et al., 2016; van Helmond et al., 2017). These sites, located in the Baltic Proper, have experienced several transitions from limnic to brackish-marine phases since the last deglaciation of the Scandinavian ice sheet (e.g., Björck., 1995).

Here we present the solid-phase major and minor element contents and Fe oxide and Fe sulfide species in deeply buried sediments in the Anholt Basin, Kattegat, retrieved during Expedition 347 (Holes M0060A and M0060B) (Tables T1, T2, T3, T4). These data allow us to (1) geochemically characterize the different depositional environments, (2) identify main biogeochemical processes and (3) elucidate the cycling of Fe and S across lithologic boundaries in the nonsteady-state depositional environment.

Table T1. Summary of the solid-phase major element data for the Anholt Basin (Holes M0060A and M0060B) drilled during Expedition 347. Download table in CSV format.

Table T2. Summary of the solid-phase minor element data for the Anholt Basin (Holes M0060A and M0060B) drilled during Expedition 347. Download table in CSV format.
Table T3. Summary of the solid-phase Fe species data for the Anholt Basin (Holes M0060A and M0060B) drilled during Expedition 347. Download table in CSV format.

Table T4. Summary of the solid-phase $\mathrm{S}$ species data for the Anholt Basin (Holes M0060A and M0060B) drilled during Expedition 347. Download table in CSV format.

\section{Methods and materials}

During Expedition 347 in 2013, on board Greatship Manisha, Holes M0060A $\left(11^{\circ} 40.243^{\prime} \mathrm{E}, \quad 56^{\circ} 37.211^{\prime} \mathrm{N}\right)$ and M0060B $\left(11^{\circ} 40.229^{\prime} \mathrm{E}, 56^{\circ} 37.204^{\prime} \mathrm{N}\right)$ were drilled using a piston corer system in $31.2 \mathrm{~m}$ water depth in the Anholt Basin with 229.6 and $85.7 \mathrm{~m}$ of core recovery, respectively (Andrén et al., 2015b). The sediment core retrieved from microbiology Hole M0060B was split on board, and the sediment core from Hole M0060A was processed during the onshore science party (OSP) at MARUM, University of Bremen (Germany), in 2014. All sediment samples were stored at $-20^{\circ} \mathrm{C}$ in $\mathrm{N}_{2}$-flushed aluminum bags.

\section{Total acid digestions and multielement analyses}

Sediment porosity was determined prior to the total acid digestions. Total acid digestions were performed in the microwave system MARS Xpress (CEM) according to the procedure described by Nöthen and Kasten (2011). Acids were of subboiling distilled $\left(\mathrm{HNO}_{3}\right.$ or $\left.\mathrm{HCl}\right)$ or suprapur (HF) quality. About $50 \mathrm{mg}$ of freezedried, homogenized bulk sediment was digested in an acid mixture of $65 \% \mathrm{HNO}_{3}(3 \mathrm{~mL}), 30 \% \mathrm{HCl}(2 \mathrm{~mL})$, and $40 \% \mathrm{HF}(0.5 \mathrm{~mL})$ at $\sim 230^{\circ} \mathrm{C}$. The digested solutions were fumed off to dryness and redissolved in $1 \mathrm{M} \mathrm{HNO}_{3}(5 \mathrm{~mL})$ at $\sim 200^{\circ} \mathrm{C}$. After full digestion, $1 \mathrm{M}$ suprapure $\mathrm{HNO}_{3}$ was added to the residue and filled up to $50 \mathrm{~mL}$. Splits of the digested solutions were taken for analysis by inductively coupled plasma-atomic emission spectroscopy (ICP-AES) and inductively coupled plasma-mass spectrometry (ICP-MS).

The multielement analysis of $\mathrm{Al}, \mathrm{Ba}, \mathrm{Ca}, \mathrm{Fe}, \mathrm{K}, \mathrm{Mg}, \mathrm{Mn}, \mathrm{Na}, \mathrm{P}, \mathrm{S}$, $\mathrm{Sr}$, and Ti was performed by ICP-AES using a Thermo Scientific IRIS Intrepid instrument. Based on replicate samples and the standard reference material NIST 2702, the analytical precision was better than 3\%. Based on the standard reference material NIST $2702(n$ $=15$ ), the analytical accuracy was $6 \%-8 \%$ for $\mathrm{Al}, \mathrm{Sr}, \mathrm{Ti}$, and $\mathrm{Mg}$ and $<5 \%$ for $\mathrm{K}, \mathrm{Ba}, \mathrm{Mn}, \mathrm{Na}, \mathrm{P}, \mathrm{Fe}, \mathrm{S}$, and $\mathrm{Ca}$.

The multielement analysis of $\mathrm{Mo}, \mathrm{V}, \mathrm{Ni}, \mathrm{Cr}, \mathrm{Ce}, \mathrm{Co}, \mathrm{U}$, and $\mathrm{Cu}$ was performed by ICP-MS using a Thermo Scientific Element2 instrument. Based on the standard reference material NIST $2702(n=$ 5), the analytical accuracy was better than $10 \%$.

\section{Sequential iron oxide extraction}

To extract different Fe pools from sediments collected at microbiology Hole M0060B, a specific sequential extraction scheme was applied after Hardisty et al. (2016). About $100 \mathrm{mg}$ of fresh anoxic sediment was treated with $10 \mathrm{~mL}$ of a $57 \mathrm{mM}$ ascorbic acid solution for $24 \mathrm{~h}$ to mobilize the most reactive Fe oxide phases, such as ferrihydrite and lepidocrocite (Reyes and Torrent, 1997). After centrifugation, a split of the supernatant extract was removed for analysis and the remaining fluid was discarded. In addition, this first extraction step extracted pore water and adsorbed Fe, which were included during analysis (Heron et al., 1994). The same procedure was performed with a $50 \mathrm{~g} / \mathrm{L}$ sodium dithionite solution buffered with $0.35 \mathrm{M}$ acetic acid and $0.2 \mathrm{M}$ sodium citrate for $2 \mathrm{~h}$ to extract crys- 
talline ferric oxides such as goethite and hematite (Mehra and Jackson, 1960; Lord, 1980; Canfield, 1989). Finally, the sediment was treated with a $0.2 \mathrm{M}$ ammonium oxalate and $0.17 \mathrm{M}$ oxalic acid solution for $6 \mathrm{~h}$ to mobilize magnetite (McKeague and Day, 1966; Poulton and Canfield, 2005; Henkel et al., 2016, 2018). Decoupled from the sequential extraction, a buffered $1 \mathrm{M}$ sodium acetate solution was added to fresh anoxic sediment samples of Hole M0060B for $24 \mathrm{~h}$, extracting Fe-associated carbonate phases (e.g., siderite and ankerite) and exchangeable metals (Tessier et al., 1979; Poulton and Canfield, 2005). During this separate extraction step, pore water and adsorbed Fe were distilled and included during analysis (Heron et al., 1994). To avoid oxidation, all solutions and sample vial headspaces were flushed with $\mathrm{N}_{2}$.

The same sequential extraction scheme (without the separate extraction of Fe-associated carbonate phases with a buffered $1 \mathrm{M}$ sodium acetate solution) was performed for Hole M0060A with $\sim 100 \mathrm{mg}$ of freeze-dried and homogenized sediment. The quantification of the extracts from Hole M0060A was performed at the Alfred Wegener Institute (Bremerhaven, Germany) by ICP-AES using a Thermo Scientific IRIS Intrepid instrument after 20-fold dilution in a $1 \mathrm{M} \mathrm{HNO}_{3}$ solution. The quantification of all extracts from Hole M0060B was performed at the University of California, Riverside (USA) using an Agilent 7500 Quadrupole ICP-MS. All extracts were analyzed upon dilution in $2 \% \mathrm{HNO}_{3}$ with Sc used as an internal standard.

\section{Sequential iron sulfide extraction}

Acid volatile sulfide (AVS; metastable Fe monosulfides) and chromium reducible S (CRS; mainly pyrite) were sequentially extracted from $0.5-1 \mathrm{~g}$ of frozen, wet sediment following the two-step acid $\mathrm{Cr}$ (II) distillation method (Canfield et al., 1986). For the extraction of $\mathrm{S}^{0}$ prior to the sequential extraction of AVS and CRS, $\sim 25 \mathrm{~mL}$ of methanol was added to the Hole M0060B samples and shaken for approximately $12 \mathrm{~h}$ (Zopfi et al., 2004). The methanol extract was decanted and analyzed by applying an acid/Cr(II) step to distill $S^{0}$. Immediately after the removal of the methanol extract, the remaining sediment was treated with a two-step acid/Cr(II) method to extract the AVS and CRS species. AVS was extracted with $6 \mathrm{M}$ $\mathrm{HCl}$ for $\sim 1 \mathrm{~h}$ at room temperature and mainly consists of Fe monosulfides such as mackinawite and approximately two-thirds of greigite (Riedinger and Brunner, 2014). Immediately after this step, the $\mathrm{Cr}$ (II) extraction was performed at $200^{\circ} \mathrm{C}$ for $\sim 2 \mathrm{~h}$. During this extraction, mainly pyrite, $\mathrm{S}^{0}$, and approximately one-third of greigite were extracted (e.g., Cornwell and Morse, 1987). The trapped sulfide $(5 \% \mathrm{w} / \mathrm{v}$ zinc acetate solution) from each step was analyzed spectrophotometrically via the methylene blue method upon dilution (Cline, 1969). Sediment samples from Hole M0060A were not analyzed for $\mathrm{S}^{0}$, and the trapped sulfide from the AVS and CRS steps was quantified gravimetrically as $\mathrm{Ag}_{2} \mathrm{~S}$. Based on the quantification of sulfide, Fe contents associated with extracted Fe monosulfides (AVS) and pyrite (CRS) were estimated under the assumption that the stoichiometry for Fe monosulfides and pyrite applies.

\section{Results and discussion}

Ratios of $\mathrm{Ti} / \mathrm{Al}$ close to the continental crustal ratio of 0.05 in clay-dominated Units II, III, and V (Figure F1) indicate steady erosion from a uniform sediment source (Wedepohl, 1995; Neumann et al., 2005). In the high-energy freshwater environment of Unit VI, the $\mathrm{Ti} / \mathrm{Al}$ ratios decrease toward the upper part of Unit VI, potentially because of gravity fractionation of heavy Ti-rich minerals during sediment transport (e.g., Chen et al., 2013). The $\mathrm{Ca} / \mathrm{Al}$ ratios generally show higher values than those expected for average continental crust. Because the $\mathrm{Ca} / \mathrm{Al}$ ratios coincide with the depth distribution of total inorganic carbon (Andrén et al., 2015b), Ca carbonates may be dominant, especially in clay-dominated Unit III (Figure F1). The K/Al ratios are mostly constant over depth and show higher values than those expected for average continental crust (Figure F1). The $\mathrm{Mg} / \mathrm{Al}$ ratios are slightly less than the crustal average and show considerably lower values in sand-dominated Units I, IV, and VI (Figure F1). In contrast, the Na/Al ratios show significantly higher values in these sandy units (Figure F1). This pattern may indicate that the terrigenous input is of $\mathrm{Na}$ - and $\mathrm{K}$-rich felsic origin (e.g., Fennoscandian Shield) and dominates over Mgbearing minerals of mafic origin, especially in sand-dominated Units I, IV, and VI. The primary sediment composition in Unit II may be altered because the pore water element/Cl ratio of $\mathrm{Ca}, \mathrm{K}$, $\mathrm{Mg}$, and $\mathrm{Na}$ indicates diagenetic reactions and/or ion exchange processes (Gieskes, 1983; Andrén et al., 2015b). The P/Al ratios are slightly less than the expected average crustal ratio, especially in sand-dominated Units I and VI (Figure F1). Thus, the P/Al depth distribution may mainly reflect a P-poor sediment source, whereas the formation of authigenic phosphate minerals, which has been observed at other sites in the Baltic Sea (e.g., Egger et al., 2015a; Dijkstra et al., 2016; März et al., 2018), does not play a major role in sediments of the Anholt Basin. The depth distribution of Sr/Al generally mimics the depth profile of $\mathrm{Ba} / \mathrm{Al}$ and has values slightly higher than those expected for the average continental crust (Figure F1). Because $\mathrm{Ba} / \mathrm{Al}$ does not show any correlation with solid-phase $\mathrm{S}$, the significant occurrence of barite can be excluded (Torres et al., 1996). The close correlation between $\mathrm{Ba}$ and $\mathrm{Sr}$ may be related to the source rock (e.g., Tarney and Jones, 1994).

The Fe/ $\mathrm{Al}$ ratios of $>0.4$ and $\mathrm{Mn} / \mathrm{Al}$ ratios of $>0.007$ indicate the dominance of Fe and $\mathrm{Mn}$ in clay-dominated Units III and V and at the Unit II/I, VI/V, and VII/VI lithologic boundaries (Figure F1). Iron and $\mathrm{Mn}$ are predominantly bound in clay minerals or occur as Fe/Mn oxides and/or diagenetic Fe sulfides (e.g., Wedepohl, 1995; Raiswell and Canfield, 1998; Poulton and Canfield, 2005). The Fe/Al ratios of $<0.4$ and $\mathrm{Mn} / \mathrm{Al}$ ratios of $<0.007$ are found in sand-dominated Units I, IV, and VI where clay minerals, Fe/Mn oxides, and Fe sulfides are minor (Figures F1, F2, F3). About 10\%-20\% of bulk Fe is bound in Fe oxides and Fe sulfides, and thus, clay minerals are the dominant Fe-bearing mineral phases, whereas about $80 \%$ of bulk $\mathrm{S}$ is associated with Fe sulfides (AVS, CRS; Figures F2, F3). Molybdenum correlates with $\mathrm{Mn} / \mathrm{Al}$, whereas the other transition metals ( $\mathrm{V}$, $\mathrm{Ni}, \mathrm{Cr}$, and $\mathrm{Co}$ ) and $\mathrm{Ce}$ coincide with the depth distribution of $\mathrm{Fe} / \mathrm{Al}$ (Figure F4). Moreover, these transition metals and Ce are associated with elevated contents of Fe oxides at the Unit II/I boundary, throughout clay-dominated Units III and V, and at the Unit VII/VI boundary, which indicates their adsorption onto Fe oxides or coupled burial. Alternatively, the elevated contents of Fe oxides, transition metals, and Ce at the Unit II/I and VII/VI boundaries may be associated with the location of the current and relict suboxic redox boundary, respectively.

Leached solid-phase contents of Fe oxides, Fe monosulfides, and pyrite vary significantly throughout the Anholt Basin sediments (Figures F2, F3). In Holes M0060A and M0060B, magnetite $\left(\mathrm{Fe}_{\text {Oxal }}\right)$ is the most abundant Fe oxide phase with contents up to $9300 \mathrm{ppm}$ (Figure F2). The highest contents of magnetite occur at the Unit II/I boundary, throughout clay-dominated Unit III, and close to the Unit V/IV and VII/VI boundaries. Crystalline Fe oxides such as goethite and hematite $\left(\mathrm{Fe}_{\text {Dith }}\right)$ generally mimic the depth profile of 
Figure F1. Solid-phase major element contents with major lithostratigraphic units, Holes M0060A (black circles) and M0060B (open circles). The vertical gray dotted line represents the continental crustal element ratio after Wedepohl (1995) and Rudnick and Gao (2003). (Adapted from Andrén et al., 2015b.)
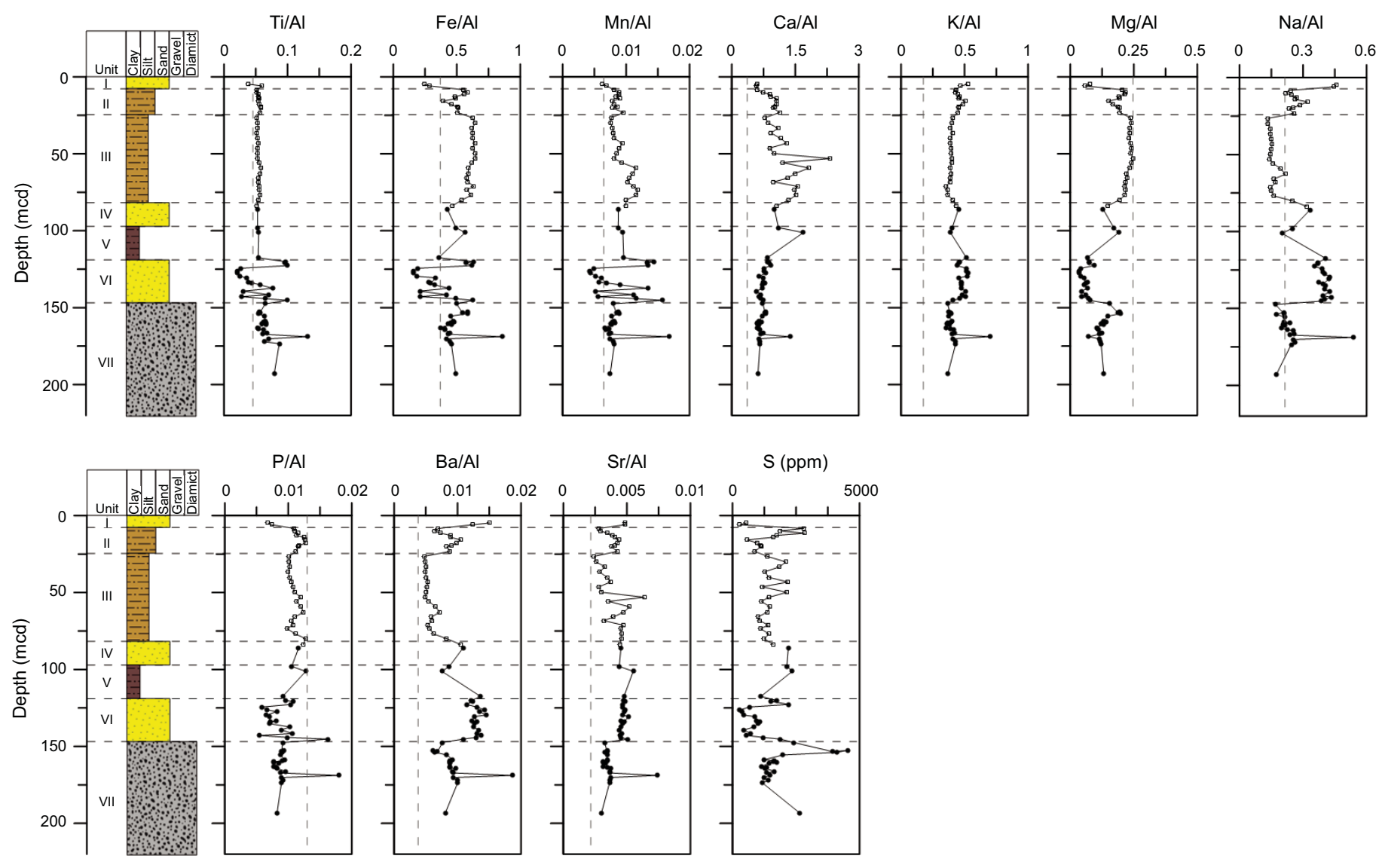

Figure F2. Solid-phase Fe oxide contents with major lithostratigraphic units, Holes M0060A (black circles) and M0060B (open circles). Fe $\mathrm{Asc}=\mathrm{ascorbate}$ extracted $\mathrm{Fe}, \mathrm{Fe}_{\mathrm{Dith}}=$ dithionite-extracted $\mathrm{Fe}, \mathrm{Fe}_{\text {Oxal }}=$ oxalate-extracted Fe. (Adapted from Andrén et al., 2015b.)

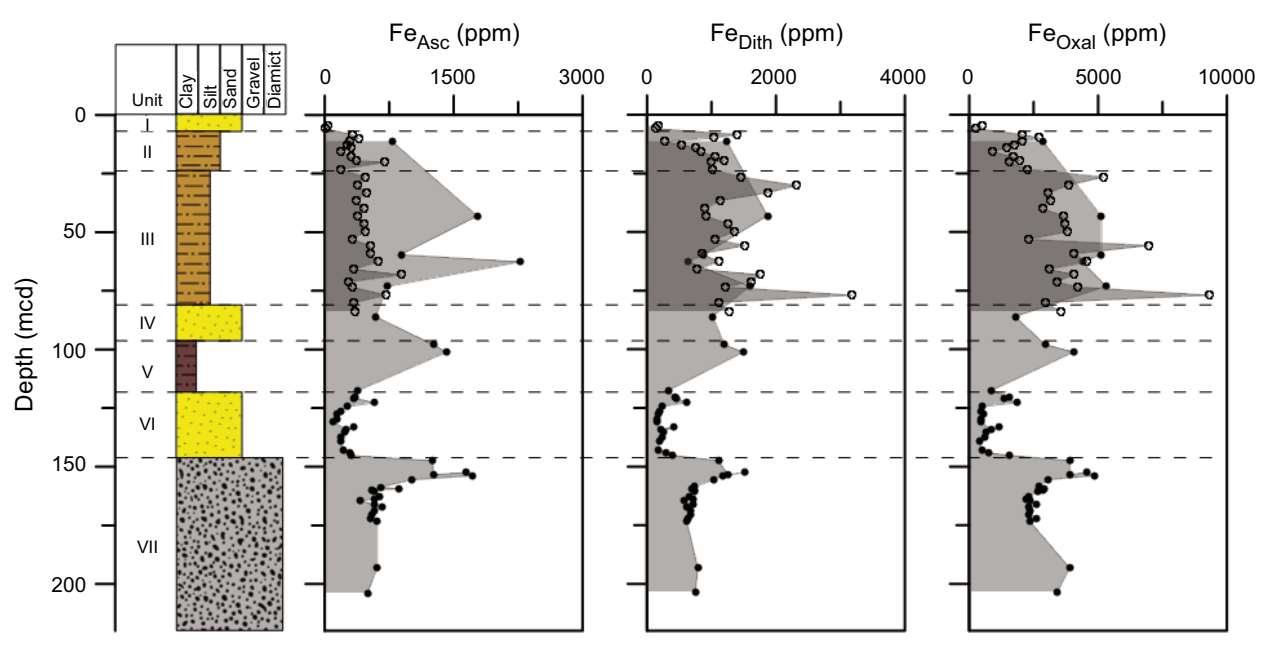

magnetite and have overall lower contents up to $3200 \mathrm{ppm}$ (Figure F2). Easily reducible Fe oxides such as ferrihydrite $\left(\mathrm{Fe}_{\mathrm{Asc}}\right)$ are less dominant in the Anholt Basin sediments and have contents up to 2300 ppm (Figure F2). Similar to magnetite and goethite/hematite, the highest contents of ferrihydrite occur in clay-dominated Unit III and close to the Unit V/IV and VII/VI boundaries. All Fe oxide fractions $\left(\mathrm{Fe}_{\mathrm{Asc}}, \mathrm{Fe}_{\mathrm{Dith}}\right.$, and $\left.\mathrm{Fe}_{\text {Oxal }}\right)$ show comparably low contents in sandy freshwater Units I, IV, and VI (Andrén et al., 2015b). The contents of carbonate-associated $\mathrm{Fe}_{\mathrm{Acet}}$ are below detection limit throughout Hole M0060B. Leached ferrihydrite contents show a two-fold offset between Holes M0060A and M0060B (Figure F2). A similar disparity in sequentially extracted Fe oxides has been observed in two independently produced data sets from Expedition 347 Site M0063 in the Landsort Deep (Hardisty et al., 2016; Dijkstra 
Figure F3. Solid-phase Fe sulfide and sulfur $\left(\mathrm{S}^{\circ}\right)$ contents with major lithostratigraphic units, Holes M0060A (black circles) and M0060B (open circles). $\mathrm{Fe} \mathrm{Avs}_{\mathrm{A}}=\mathrm{Fe}$ associated with acid volatile sulfur, $\mathrm{Fe}_{\mathrm{CRS}}=\mathrm{Fe}$ associated with chromium reducible sulfur). (Adapted from Andrén et al., 2015b.)

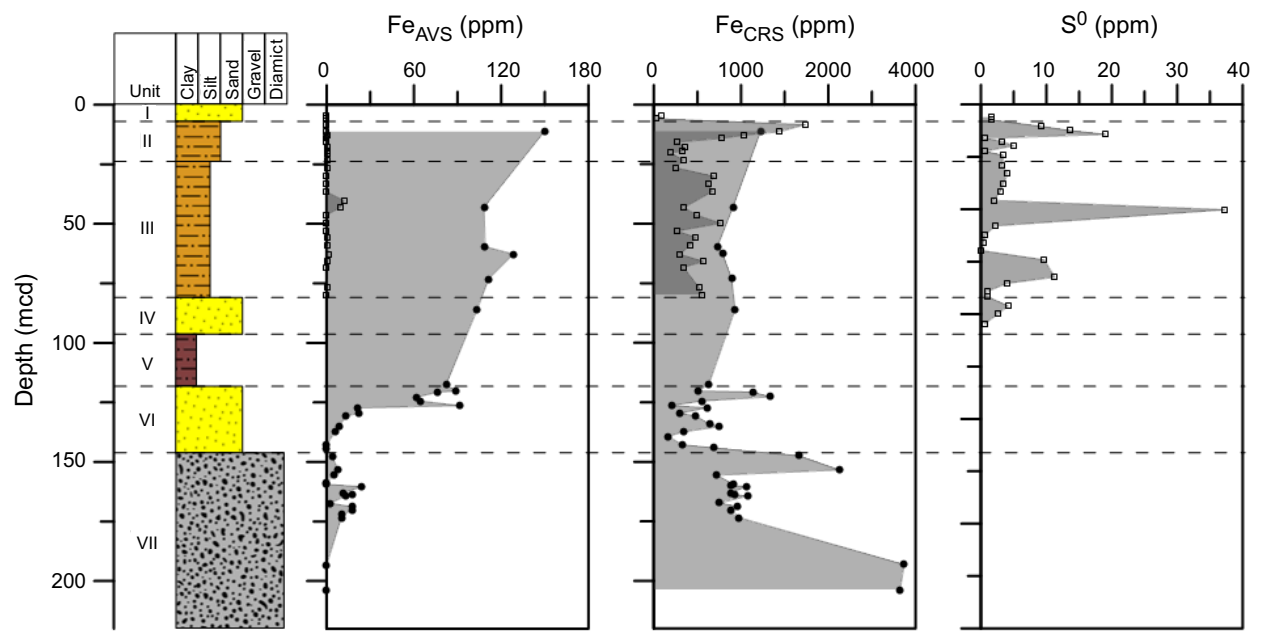

Figure F4. Solid-phase minor element contents with major lithostratigraphic units, Holes M0060A (black circles) and M0060B (open circles). (Adapted from Andrén et al., 2015b.)

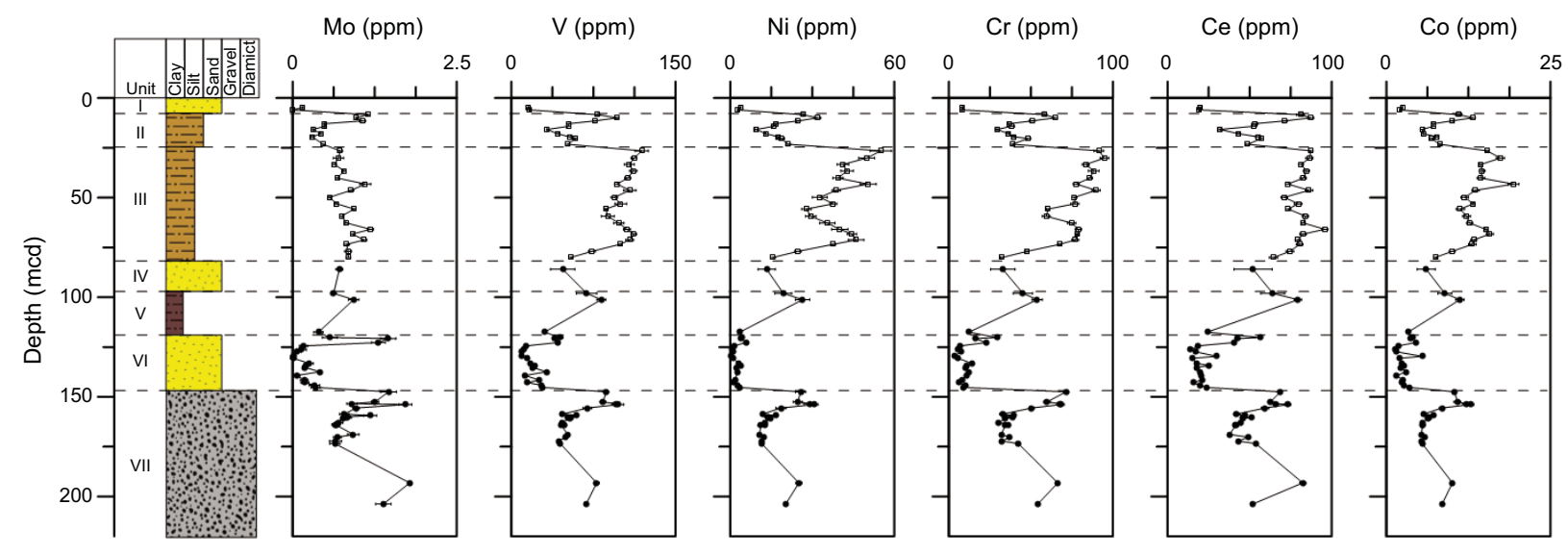

et al., 2016). Hardisty et al. (2016) performed the sequential extraction of Fe oxides with freshly thawed sediments, and Dijkstra et al. (2016) used dried sediments. Furthermore, instead of using ascorbic acid as the extracting agent for the most reactive Fe oxide fraction, such as ferrihydrite, Dijkstra et al. (2016) applied hydroxylamine- $\mathrm{HCl}$ (after the procedure of Poulton and Canfield, 2005). These methodological differences resulted on average in 20-fold higher ferrihydrite contents determined by Dijkstra et al. (2016) compared to results by Hardisty et al. (2016). Because the process of freeze-drying might increase the crystallinity of Fe oxides (Rapin et al., 1986) and thereby bias the leached content, the sequentially extracted Fe oxide contents from freshly thawed sediments may be more accurate.

Pyrite (CRS) is the dominant Fe sulfide phase in the Anholt Basin sediments and shows at least 10-fold higher contents compared to the Fe monosulfides (AVS) (Figure F3). Highest contents of pyrite (almost 3000 ppm) occur in Unit VII below 190 meters composite depth (mcd). Pyrite peaks occur at the lithologic boundaries of Units II/I, VI/V, and VII/VI. The offset in Fe monosulfide contents between Holes M0060A and M0060B may be due to different sample quality (Hole M0060B cores were sampled on board; Hole
M0060A cores were sampled during the OSP) and/or extraction artifacts resulting from the additional sequential leaching step for the extraction of $\mathrm{S}^{0}$ from Hole M0060B sediments. The $\mathrm{S}^{0}$ contents are usually well below $10 \mathrm{ppm}$ throughout Hole M0060B (Figure F3). Elevated $S^{0}$ contents occur at the Unit II/I boundary and within Unit III at 40 and $66 \mathrm{mcd}$, which coincides with the occurrence of Fe sulfide bands (Andrén et al., 2015b). However, because the freshly thawed sediments used for the extraction of $S^{0}$ were not fixed in zinc acetate during the leaching step itself, $\mathrm{S}^{0}$ contents may be underestimated because of oxidation processes during extraction (Zopfi et al., 2004).

Based on pore water constituents, dissimilatory sulfate and Fe oxide reduction are the main microbial degradation processes at Site M0060 (Andrén et al., 2015b). Pore water Fe ${ }^{2+}$ occurs mainly in Units III, VI, and VII, but pore water sulfide is absent throughout. Iron sulfides are probably produced at the Unit II/I boundary by the direct consumption of pore water sulfide with $\mathrm{Fe}^{2+}$, both of which are released during the degradation of organic matter (Figure F3). Through the addition of $\mathrm{S}^{0}$, metastable Fe monosulfides are probably being converted into pyrite at the Unit II/I boundary. The pore water sulfate profile indicates a second dissimilatory sulfate reduc- 
tion zone at about 60 mcd in Unit III (Andrén et al., 2015b). Concurrently, $\mathrm{Fe}^{2+}$ strongly decreases downhole, indicating its consumption at $60 \mathrm{mcd}$. In accordance with the occurrence of Fe sulfide bands in this interval (Andrén et al., 2015b), only small amounts of Fe monosulfides are being converted to pyrite.

The methane peak in the methanic zone of Unit VII coincides with high amounts of all Fe oxide fractions and pyrite (Figures F2, F3). Because $\mathrm{Fe}^{2+}$ concentrations increase with depth throughout Unit VI, methane is potentially consumed by the anaerobic oxidation with Fe oxides (e.g., Riedinger et al., 2014; Egger et al., 2015b, 2017; Aromokeye et al., 2020). The availability of pyrite at the Unit VII/VI boundary may indicate that sulfate and Fe oxides have been concurrently reduced during the anaerobic oxidation of methane, resulting in the formation of pyrite via metastable Fe monosulfides. Thus, the enrichment of Fe monosulfides and pyrite at the Unit VI/V boundary may represent a relict sulfate-methane transition. Compared to the other sites that have been studied within the framework of Expedition 347 (e.g., Bornholm Basin and Landsort Deep [e.g., Hardistry et al., 2016; van Helmond et al. 2017; Papadomanolaki et al., 2018]), the contents of the redox-sensitive elements (e.g., Mn and Mo) are relatively low and do not indicate temporarily anoxic water column conditions in the Anholt Basin.

\section{Acknowledgments}

This research used samples and data provided by the Integrated Ocean Drilling Program (IODP). We greatly acknowledge the outstanding efforts of the crew and drilling personnel onboard Greatship Manisha, the shipboard and onshore scientific parties, and the Co-Chief Scientists Thomas Andrén and Bo Barker Jørgensen. D.S. Hardisty and N. Riedinger acknowledge support by the Consortium for Ocean Leadership-U.S. Science Support Program. We thank David B. McInroy and Timothy G. Ferdelman for editing and reviewing this data report.

\section{References}

Aromokeye, D.A., Kulkarni, A.C., Elvert, M., Wegener, G., Henkel, S., Coffinet, S., Eickhorst, T., et al., 2020. Rates and microbial players of irondriven anaerobic oxidation of methane in methanic marine sediments. Frontiers in Microbiology, 10:3041.

https://doi.org/10.3389/fmicb.2019.03041

Andrén, T., Björck, S., Andrén, E., Conley, D., Zillén, L., and Anjar, J., 2011. The development of the Baltic Sea Basin during the last $130 \mathrm{ka}$. In Harff, J., Björck, S., and Hoth, P. (Eds.), Central and Eastern European Development Studies (CEEDES): The Baltic Sea Basin: Berlin (Springer), 75-97. https://doi.org/10.1007/978-3-642-17220-5_4

Andrén, T., Jørgensen, B.B., Cotterill, C., Green, S., and the IODP Expedition 347 Scientific Party, 2015a. IODP Expedition 347: Baltic Sea Basin paleoenvironment and biosphere. Scientific Drilling, 20:1-12. https://doi.org/10.5194/sd-20-1-2015

Andrén, T., Jørgensen, B.B., Cotterill, C., Green, S., Andrén, E., Ash, J., Bauersachs, T., Cragg, B., Fanget, A.-S., Fehr, A., Granoszewski, W., Groeneveld, J., Hardisty, D., Herrero-Bervera, E., Hyttinen, O., Jensen, J.B., Johnson, S., Kenzler, M., Kotilainen, A., Kotthoff, U., Marshall, I.P.G., Martin, E., Obrochta, S., Passchier, S., Quintana Krupinski, N., Riedinger, N., Slomp, C., Snowball, I., Stepanova, A., Strano, S., Torti, A., Warnock, J., Xiao, N., and Zhang, R., 2015b. Site M0060. In Andrén, T., Jørgensen, B.B., Cotterill, C., Green, S., and the Expedition 347 Scientists, Proceedings of the Integrated Ocean Drilling Program, 347: College Station, TX (Integrated Ocean Drilling Program).

https://doi.org/10.2204/iodp.proc.347.104.2015
Berner, R.A., 1984. Sedimentary pyrite formation: an update. Geochimica et Cosmochimica Acta, 48(4):605-615. https://doi.org/10.1016/0016-7037(84)90089-9

Berner, R.A., 1970. Sedimentary pyrite formation. American Journal of Science, 268(1):1-23. https://doi.org/10.2475/ajs.268.1.1

Björck, S., 1995. A review of the history of the Baltic Sea, 13.0-8.0 ka BP. Quaternary International, 27:19-40. https://doi.org/10.1016/1040-6182(94)00057-C

Brumsack, H.-J., 2006. The trace metal content of recent organic carbon-rich sediments: implications for Cretaceous black shale formation. Palaeogeography, Palaeoclimatology, Palaeoecology, 232(2-4):344-361. https://doi.org/10.1016/j.palaeo.2005.05.011

Canfield, D.E., 1989. Reactive iron in marine sediments. Geochimica et Cosmochimica Acta, 53(3):619-632. https://doi.org/10.1016/0016-7037(89)90005-7

Canfield, D.E., Raiswell, R., Westrich, J.T., Reaves, C.M., and Berner, R.A., 1986. The use of chromium reduction in the analysis of reduced inorganic sulfur in sediments and shales. Chemical Geology, 54(1-2):149-155. https://doi.org/10.1016/0009-2541(86)90078-1

Chen, H.-F., Yeh, P.-Y., Song, S.-R., Hsu, S.-C., Yang, T.-N., Wang, Y., Chi, Z., et al., 2013. The $\mathrm{Ti} / \mathrm{Al}$ molar ratio as a new proxy for tracing sediment transportation processes and its application in aeolian events and sea level change in East Asia. Journal of Asian Earth Sciences, 73:31-38. https://doi.org/10.1016/j.jseaes.2013.04.017

Cline, J.D., 1969. Spectrophotometric determination of hydrogen sulfide in natural waters. Limnology and Oceanography, 14(3):454-458. https://doi.org/10.4319/lo.1969.14.3.0454

Cornwell, J.C., and Morse, J.W., 1987. The characterization of iron sulfide minerals in anoxic marine sediments. Marine Chemistry, 22(2-4):193206. https://doi.org/10.1016/0304-4203(87)90008-9

Dijkstra, N., Slomp, C.P., Behrends, T., and Expedition 347 Scientists, 2016. Vivianite is a key sink for phosphorus in sediments of the Landsort Deep, an intermittently anoxic deep basin in the Baltic Sea. Chemical Geology, 438:58-72. https://doi.org/10.1016/j.chemgeo.2016.05.025

Egger, M., Hagens, M., Sapart, C.J., Dijkstra, N., van Helmond, N.A.G.M., Mogollón, J.M., Risgaard-Petersen, N., van der Veen, C., et al., 2017. Iron oxide reduction in methane-rich deep Baltic Sea sediments. Geochimica et Cosmochimica Acta, 207:256-276. https://doi.org/10.1016/j.gca.2017.03.019

Egger, M., Jilbert, T., Behrends, T., Rivard, C., and Slomp, C.P., 2015a. Vivianite is a major sink for phosphorus in methanogenic coastal surface sediments. Geochimica et Cosmochimica Acta, 169:217-235. https://doi.org/10.1016/j.gca.2015.09.012

Egger, M., Rasigraf, O., Sapart, C.J., Jilbert, T., Jetten, M.S.M., Röckmann, T., van der Veen, C., et al., 2015b. Iron-mediated anaerobic oxidation of methane in brackish coastal sediments. Environmental Science and Technology, 49(1):277-283. https://doi.org/10.1021/es503663z

Eronen, M., 1990. The evolution of the Baltic Sea. In Alalammi, P. (Ed), Atlas of Finland: Helsinki, Finland (National Board of Survey and Geographical Society of Finland), 123-126.

Froelich, P.N., Klinkhammer, G.P., Bender, M.L., Luedtke, N.A., Heath, G.R., Cullen, D., Dauphin, P., Hammond, D., Hartman, B., and Maynard, V., 1979. Early oxidation of organic matter in pelagic sediments of the eastern equatorial Atlantic: suboxic diagenesis. Geochimica et Cosmochimica Acta, 43(7):1075-1090. https://doi.org/10.1016/0016-7037(79)90095-4

Gieskes, J.M., 1983. The chemistry of interstitial waters of deep sea sediments: interpretation of deep sea drilling data. In Riley, J.P., and Chester, R. (Eds.), Chemical Oceanography (Volume 8): London (Academic), 221-269. https://doi.org/10.1016/B978-0-12-588608-6.50010-9

Goldhaber, M.B., and Kaplan, I.R., 1974. The sulfur cycle. In Goldberg, E.D., The Sea (Volume 5): Marine Chemistry: Hoboken, NJ (John Wiley \& Sons, Inc.), 569-655.

Hardisty, D.S., Riedinger, N., Planavsky, N.J., Asael, D., Andrén, T., Jørgensen, B.B., and Lyons, T.W., 2016. A Holocene history of dynamic water column 
redox conditions in the Landsort Deep, Baltic Sea. American Journal of Science, 316(8):713-745. https://doi.org/10.2475/08.2016.01

Henkel, S., Kasten, S., Hartmann, J.F., Silva-Busso, A., and Staubwasser, M., 2018. Iron cycling and stable Fe isotope fractionation in Antarctic shelf sediments, King George Island. Geochimica et Cosmochimica Acta, 237:320-338. https://doi.org/10.1016/j.gca.2018.06.042

Henkel, S., Kasten, S., Poulton, S.W., and Staubwasser, M., 2016. Determination of the stable iron isotopic composition of sequentially leached iron phases in marine sediments. Chemical Geology, 421:93-102. https://doi.org/10.1016/j.chemgeo.2015.12.003

Hensen, C., Zabel, M., Pfeifer, K., Schwenk, T., Kasten, S., Riedinger, N., Schulz, H.D., and Boetius, A., 2003. Control of sulfate pore-water profiles by sedimentary events and the significance of anaerobic oxidation of methane for the burial of sulfur in marine sediments. Geochimica et Cosmochimica Acta, 67(14):2631-2647. https://doi.org/10.1016/S0016-7037(03)00199-6

Heron, G., Crouzet, C., Bourg, A.C.M., and Christensen, T.H., 1994. Speciation of $\mathrm{Fe}(\mathrm{II})$ and $\mathrm{Fe}(\mathrm{III})$ in contaminated aquifer sediments using chemical extraction techniques. Environmental Science and Technology, 28(9):1698-1705. https://doi.org/10.1021/es00058a023

Jørgensen, B.B., 1982. Mineralization of organic matter in the sea bed-the role of sulphate reduction. Nature, 296(5858):643-645. https://doi.org/10.1038/296643a0

Jørgensen, B.B., 1977. The sulfur cycle of a coastal marine sediment (Limfjorden, Denmark). Limnology and Oceanography, 22(5):814-832. https://doi.org/10.4319/lo.1977.22.5.0814

Jørgensen, B.B., and Kasten, S., 2006. Sulfur cycling and methane oxidation. In Schulz, H.D., and Zabel, M. (Eds.), Marine Geochemistry: Berlin (Springer), 271-309. https://doi.org/10.1007/3-540-32144-6_8

Kotthoff, U., Groeneveld, J., Ash, J.L., Fanget, A.-S., Quintana Krupinski, N., Peyron, O., Stepanova, A., et al., 2017. Reconstructing Holocene temperature and salinity variations in the western Baltic Sea region: a multi-proxy comparison from the Little Belt (IODP Expedition 347, Site M0059). Biogeosciences, 14(23):5607-5632. https://doi.org/10.5194/bg-14-5607-2017

Lord, C.J., III, 1980. The chemistry and cycling of iron, manganese, and sulfur in a salt marsh sediment [Ph.D. dissertation]. University of Delaware, Newark.

Luther, G.W., III, 1991. Pyrite synthesis via polysulfide compounds. Geochimica et Cosmochimica Acta, 55(10):2839-2849. https://doi.org/10.1016/0016-7037(91)90449-F

März, C., Riedinger, N., Sena, C., and Kasten, S., 2018. Phosphorus dynamics around the sulphate-methane transition in continental margin sediments: authigenic apatite and Fe(II) phosphates. Marine Geology, 404:84-96. https://doi.org/10.1016/j.margeo.2018.07.010

McKeague, J.A., and Day, J.H., 1966. Dithionite- and oxalate-extractable Fe and $\mathrm{Al}$ as aids in differentiating various classes of soils. Canadian Journal of Soil Science, 46(1):13-22. https://doi.org/10.4141/cjss66-003

Mehra, O.P., and Jackson, M.L., 1960. Iron oxide removal from soils and clays by a dithionite-citrate system buffered with sodium bicarbonate. Clays and Clay Minerals, 2013:317-327. https://doi.org/10.1016/B978-0-08-009235-5.50026-7

Miettinen, A., 2004. Holocene sea-level changes and glacio-isostasy in the Gulf of Finland, Baltic Sea. Quaternary International, 120(1):91-104. https://doi.org/10.1016/j.quaint.2004.01.009

Neumann, T., Rausch, N., Leipe, T., Dellwig, O., Berner, Z., and Böttcher, M.E., 2005. Intense pyrite formation under low-sulfate conditions in the Achterwasser lagoon, SW Baltic Sea. Geochimica et Cosmochimica Acta, 69(14):3619-3630. https://doi.org/10.1016/j.gca.2005.02.034

Niewöhner, C., Hensen, C., Kasten, S., Zabel, M., and Schulz, H.D, 1998. Deep sulfate reduction completely mediated by anaerobic methane oxidation in sediments of the upwelling area off Namibia. Geochimica et Cosmochimica Acta, 62(3):455-464. https://doi.org/10.1016/S0016-7037(98)00055-6

Nöthen, K., and Kasten, S., 2011. Reconstructing changes in seep activity by means of pore water and solid phase $\mathrm{Sr} / \mathrm{Ca}$ and $\mathrm{Mg} / \mathrm{Ca}$ ratios in pockmark sediments of the Northern Congo Fan. Marine Geology, 287(1-4):1-13. https://doi.org/10.1016/j.margeo.2011.06.008

Oni, O., Miyatake, T., Kasten, S., Richter-Heitmann, T., Fischer, D., Wagenknecht, L., Kulkarni, A., et al., 2015. Distinct microbial populations are tightly linked to the profile of dissolved iron in the methanic sediments of the Helgoland mud area, North Sea. Frontiers in Microbiology, 6:365. https://doi.org/10.3389/fmicb.2015.00365

Papadomanolaki, N.M., Dijkstra, N., van Helmond, N.A.G.M., Hagens, M., Bauersachs, T., Kotthoff, U., Sangiorgi, F., and Slomp, C.P., 2018. Controls on the onset and termination of past hypoxia in the Baltic Sea. Paleogeography, Paleoclimatology, Paleoecology, 490:347-354.

https://doi.org/10.1016/j.palaeo.2017.11.012

Poulton, S.W., and Canfield, D.E., 2005. Development of a sequential extraction procedure for iron: implications for iron partitioning in continentally derived particulates. Chemical Geology, 214(3-4):209-221. https://doi.org/10.1016/j.chemgeo.2004.09.003

Raiswell, R., and Canfield, D.E., 1998. Sources of iron for pyrite formation in marine sediments. American Journal of Science, 298(3):219-245. https://doi.org/10.2475/ajs.298.3.219

Rapin, F., Tessier, A., Campbell, P.G.C., and Carignan, R., 1986. Potential artifacts in the determination of metal partitioning in sediments by a sequential extraction procedure. Environmental Science and Technology, 20(8):836-840. https://doi.org/10.1021/es00150a014

Reyes, I., and Torrent, J., 1997. Citrate-ascorbate as a highly selective extractant for poorly crystalline iron oxides. Soil Science Society of America Journal, 61(6):1647-1654.

https://doi.org/10.2136/sssaj1997.03615995006100060015x

Richardson, K., and Heilmann, J.P., 1995. Primary production in the Kattegat: past and present. Ophelia, 41(1):317-328. https://doi.org/10.1080/00785236.1995.10422050

Rickard, D., 1995. Kinetics of FeS precipitation: Part 1. Competing reaction mechanisms. Geochimica et Cosmochimica Acta, 59(21):4367-4379. https://doi.org/10.1016/0016-7037(95)00251-T

Rickard, D., 1997. Kinetics of pyrite formation by the $\mathrm{H}_{2} \mathrm{~S}$ oxidation of iron (II) monosulfide in aqueous solutions between 25 and $125^{\circ} \mathrm{C}$ : the rate equation. Geochimica et Cosmochimica Acta, 61(1):115-134. https://doi.org/10.1016/S0016-7037(96)00321-3

Rickard, D.T., 1975. Kinetics and mechanism of pyrite formation at low temperatures. American Journal of Science, 275(6):636-652. https://doi.org/10.2475/ajs.275.6.636

Riedinger, N., and Brunner, B., 2014. Data report: concentration and sulfur isotope composition of iron monosulfide and pyrite from sediments collected during IODP Expedition 316. In Kinoshita, M., Tobin, H., Ashi, J., Kimura, G., Lallemant, S., Screation, E.J., Curewitz, D., Masago, H., Moe, K.T., and the Expedition 314/315/316 Scientists, Proceedings of the Integrated Ocean Drilling Program, 314/315/316: Washington, DC (Integrated Ocean Drilling Program Management International, Inc.). https://doi.org/10.2204/iodp.proc.314315316.223.2014

Riedinger, N., Formolo, M.J., Lyons, T.W., Henkel, S., Beck, A., and Kasten, S., 2014. An inorganic geochemical argument for coupled anaerobic oxidation of methane and iron reduction in marine sediments. Geobiology, 12(2):172-181. https://doi.org/10.1111/gbi.12077

Riedinger, N., Pfeifer, K., Kasten, S., Garming, J.F.L., Vogt, C., and Hensen, C., 2005. Diagenetic alteration of magnetic signals by anaerobic oxidation of methane related to a change in sedimentation rate. Geochimica et Cosmochimica Acta, 69(16):4117-4126. https://doi.org/10.1016/j.gca.2005.02.004

Rudnick, R.L., and Gao, S., 2003. Composition of the continental crust. In Holland, H.D., and Turekian, K.K. (Eds.), Treatise on Geochemistry (Volume 3): The Crust: Oxford (Elsevier-Pergamon) 1-64. https://doi.org/10.1016/B0-08-043751-6/03016-4

Stigebrandt, A., 1983. A model for the exchange of water and salt between the Baltic and the Skagerrak. Journal of Physical Oceanography, 13(3):411427. https://doi.org/10.1175/1520-0485(1983)013<0411:AMFTEO $>2.0 . C O ; 2$ 
Svansson, A., 1975. Physical and chemical oceanography of the Skagerrak and the Kattegat. Fishery Board of Sweden, Institute of Marine Research Report. http://hdl.handle.net/2077/49089

Tarney, J., and Jones, C.E., 1994. Trace element geochemistry or orogenic igneous rocks and crustal growth models. Journal of the Geological Society (London, United Kingdom), 151:855-868. https://doi.org/10.1144/gsjgs.151.5.0855

Tessier, A., Campbell, P.G.C., and Bisson, M., 1979. Sequential extraction procedure for the speciation of particulate trace metals. Analytical Chemistry, 51(7):844-851. https://doi.org/10.1021/ac50043a017

Thamdrup, B., Fossing, H., and Jørgensen, B.B., 1994. Manganese, iron and sulfur cycling in a coastal marine sediment, Aarhus bay, Denmark. Geochimica et Cosmochimica Acta, 58(23):5115-5129. https://doi.org/10.1016/0016-7037(94)90298-4

Thiel, J., Byrne, J.M., Kappler, A., Schink, B., and Pester, M., 2019. Pyrite formation from $\mathrm{FeS}$ and $\mathrm{H}_{2} \mathrm{~S}$ is mediated through microbial redox activity. Proceedings of the National Academy of Sciences of the United States of America, 116(14):6897-6902.

https://doi.org/10.1073/pnas.1814412116
Torres, M.E., Brumsack, H.-J., Bohrmann, G., and Emeis, K.C., 1996. Barite fronts in continental margin sediments: a new look at barium remobilization in the zone of sulfate reduction and formation of heavy barites in diagenetic fronts. Chemical Geology, 127(1-3):125-139. https://doi.org/10.1016/0009-2541(95)00090-9

van Helmond, N.A.G.M., Quintana Krupinski, N.B., Lougheed, B.C., Obrochta, S.P., Andrén, T., and Slomp, C.P., 2017. Seasonal hypoxia was a natural feature of the coastal zone in the Little Belt, Denmark, during the past 8 ka. Marine Geology, 387:45-57. https://doi.org/10.1016/j.margeo.2017.03.008

Wedepohl, K.H., 1995. The composition of the continental crust. Geochimica et Cosmochimica Acta, 59(7):1217-1232. https://doi.org/10.1016/0016-7037(95)00038-2

Zopfi, J., Ferdelman, T.G., and Fossing, H., 2004. Distribution and fate of sulfur intermediates-sulfite, tetrathionate, thiosulfate, and elemental sulfur-in marine sediments. In Amend, J.P., Edwards, K.J., and Lyons, T.W. (Eds), Sulfur Biochemistry - Past and Present. Special Paper - Geological Society of America, 379:97-116.

https://doi.org/10.1130/0-8137-2379-5.97 